DOI: $10.17148 /$ IARJSET.2021.8780

\title{
Fabrication and Analysis of Parabolic Concentrated Solar Water Heater with Solar Tracking System
}

\author{
Gaurav Pandey ${ }^{1}$, Amit Kumar Singh ${ }^{2}$, Shivanshu Kumar ${ }^{3}$, Er.Vivek Agnihotri ${ }^{4}$, \\ Er.Mayank Kumar ${ }^{5}$ \\ Mechanical Engineering Department, Shri Ramswaroop Memorial College of Engineering and Management, \\ Lucknow, Uttar Pradesh, India ${ }^{1,2,3}$ \\ Faculty member in mechanical department at SRMCEM, Lucknow Uttar Pradesh, India ${ }^{4,5}$
}

\begin{abstract}
The purpose of this project is to fabricates and conduct experimental or analysis work on parabolic concentrated solar water heater with solar tracking system that can heat the water from nearly any sources, a system that is relatively cheap, portable, and depends only on renewable solar energy. The motivation for this project is there are many applications of solar thermal energy in different temperature range such as high temperature ranges (above $448 \mathrm{~K}$ ) medium temperature ranges (373K to $448 \mathrm{~K}$ ) and low temperature ranges (below $273 \mathrm{~K}$ ) and one more motivation is their application in agricultural and industrial process heat. Our project goal is to promotes the more and more use of renewable energy resources and to fabrication and analysis or experimental work on parabolic concentrated solar water heater with solar tracking system (manual tracking). Another objective of the project is to understand various components, various relation and equation related to making of solar parabolic collector, and also various relations related to tracking system such as plot sun path diagram, understand solar radiation geometry and also understand the estimation of average solar radiation and analysis of parabolic concentrating collectors. To interpret the results from tabulated values taken from observation. The project entitled Fabrication and analysis of parabolic concentrated solar water heater with solar tracking system consisting the two main works which are as follows: -1 - Fabrication works 2 - Analysis or experimental data calculation works. Fabrications works contains the different fabricated works such as making of parabolic shaped rib skeletons which provide supports to the reflecting surface (such as steel reflecting sheet and chromium reflecting sheets), making of parabolic trough collector, receiver tubes fitting, and making of balances system to provide balances to the system. The analysis or experiment work is conducted with water as a working fluid and reading taken for different flow rates and reflecting surfaces. The calculated values will be tabulated, graphs will be plot and hence efficiency and their performances will be determined for the experimental setups.
\end{abstract}

Keywords: Parabolic concentrating collector, sun path diagram, solar geometry, Manual tracking system, Parabolic rib skeletons.

\section{INTRODUCTION}

Concentrating or Focussing collector is a device to collects solar energy with high intensity of solar radiation on the energy absorbing surfaces. Such collectors generally use optical system in the form of reflectors or refractors. A focusing collector is a special form of flat plate collector modified by introducing a reflecting (or refracting) surface (concentrators) between solar radiations and the absorber. These types of collectors can have radiation increases from low values of 1.5 to 2 to high values of the order of 10,000. In these collectors' radiation failing on a relatively large area is focused on to a receiver (or absorber) of considerably smaller area. As a results of the energy concentration, fluids can be heated to temperatures $500^{\circ} \mathrm{C}$ or more. An importance difference between collectors of the non-focusing and focusing types in that the latter concentrate only direct radiation coming from a specific direction, since diffuse radiation arrives from all directions, only a very small proportion is the from the direction for which focusing occurs. The optical system directs the solar radiation on to an absorber of smaller area which is usually surrounded by a transparent cover because of the optical system, certain losses (in addition to those which occur while the radiation is transmitted through the cover) are introduced. These include reflection and absorption. 
International Advanced Research Journal in Science, Engineering and Technology

Vol. 8, Issue 7, July 2021

DOI: $10.17148 /$ IARJSET.2021.8780

METHODOLOGY

Steps involved in Methodology of the proposed project works can be explained through given flow charts:

Collection of data through literature available

Detailed studies about parabolic trough collectors such their components, materials etc.

Study and search about compact shape and size of the project and made decision for all the dimensions of the project proposed models and

making of hand drawing of the project different view with proper dimensioning

Collected all data, material and components related to parabolic concentrated solar water heater from market

Fabrication of the proposed project works components

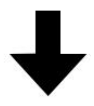

Assembly of the components of the project proposed model

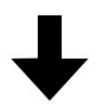

Analysis and Experimental work

Result , calculations and made data interpretation related to the project work

Conclusion and future scope of the project works 
Vol. 8, Issue 7, July 2021

\section{DOI: $10.17148 /$ IARJSET.2021.8780 \\ III FABRICATIONS WORKS}

Fabrication of parabolic trough concentrated solar water heater is an important part of the project making in which we fabricate the different parts or components of the proposed projects works which are as:

1. Fabrication of parabolic trough collector.

2. Fabrication of the balance system to provides the support to whole structure or frame of the projects model.

3. Fabrication of receiver tube.

4. Arrangement for water inlet and water outlet valve with the receiver.

5. Fabrication of rib skeleton which support the parabolic trough.

6. Fabrication of manual tracking system

7. Fabrication of elevated and horizontal frame structure for the PTC

- Two methods are used in Drawing of parabolic shape:

Method 1: - simple drawing methods:

Create a Parabola from Lines and a Right-Angle

Step 1: - Draw a right angle and mark two lines of equal length at equal intervals. It should look like you are making a coordinate plane to graph an equation.

Step 2: - Draw a line from the farthest mark from the right angle on one line, to the closest mark to the right angle on the other line.

Step 3: - Now connect the 2nd farthest mark to the 2nd closest mark.

Step 4: - Continue connecting lines between the points as you step down one line and step up the other.

Step 5: - Here we have rotated the image 45 degrees so the parabola is oriented in the conventional way.

Step 6: - The curve was pretty smooth looking with eight marks on each line, but can be made smoother by adding more marks. There are 32 in this picture.

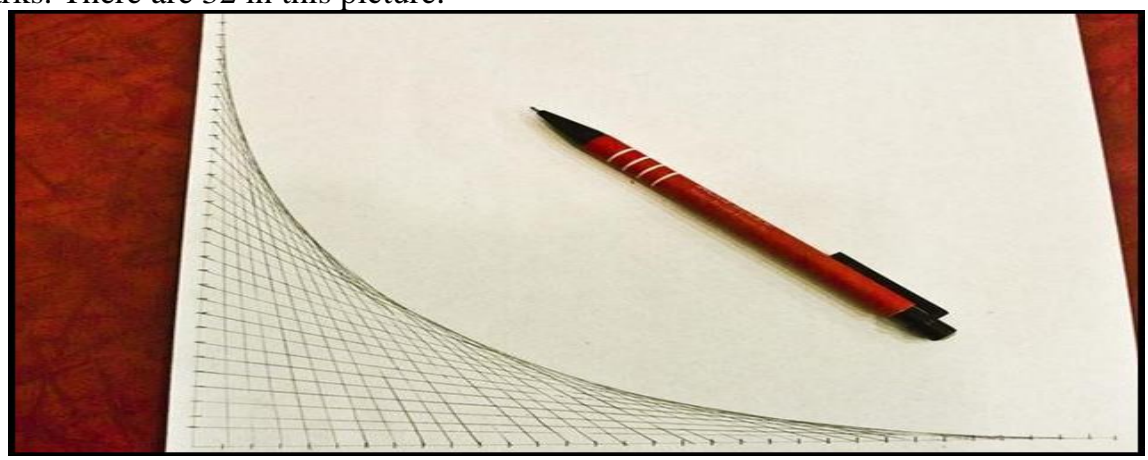

Methods 2: - analytical methods: -

Equation : - Parabolice Shape.

$$
\begin{aligned}
& y=x^{2} / 4 f \\
& y=x^{2} \div(4 \times 320) \\
& y=0.0007813 x^{2}
\end{aligned}
$$

Putting the different value of $\mathrm{x}$ in above equation we will get a parabola

The value of $x$, taken from Fabricated experiment:

\begin{tabular}{|r|c|}
\hline $\mathbf{x}$ & .007813x $^{2}$ \\
\hline-600 & 281.268 \\
\hline-550 & 236.34325 \\
\hline-500 & 195.325 \\
\hline-450 & 158.21325 \\
\hline-400 & 125.008 \\
\hline-350 & 95.70925 \\
\hline
\end{tabular}


International Advanced Research Journal in Science, Engineering and Technology

Vol. 8, Issue 7 , July 2021

DOI: $10.17148 /$ IARJSET.2021.8780

\begin{tabular}{|c|c|}
\hline-300 & 70.317 \\
\hline-250 & 48.83125 \\
\hline-200 & 31.252 \\
\hline-150 & 17.57925 \\
\hline-100 & 7.813 \\
\hline-3 & 0.0070317 \\
\hline-2 & 0.0031252 \\
\hline-1 & 0.0007813 \\
\hline 0 & 0 \\
\hline 1 & 1 \\
\hline 2 & 0.0031252 \\
\hline 3 & 0.0070317 \\
\hline 50 & 1.95325 \\
\hline 100 & 7.813 \\
\hline 150 & 17.57925 \\
\hline 200 & 31.252 \\
\hline 250 & 48.83125 \\
\hline
\end{tabular}

With reference of above value, draw the graph:

Graphical curve of parabola

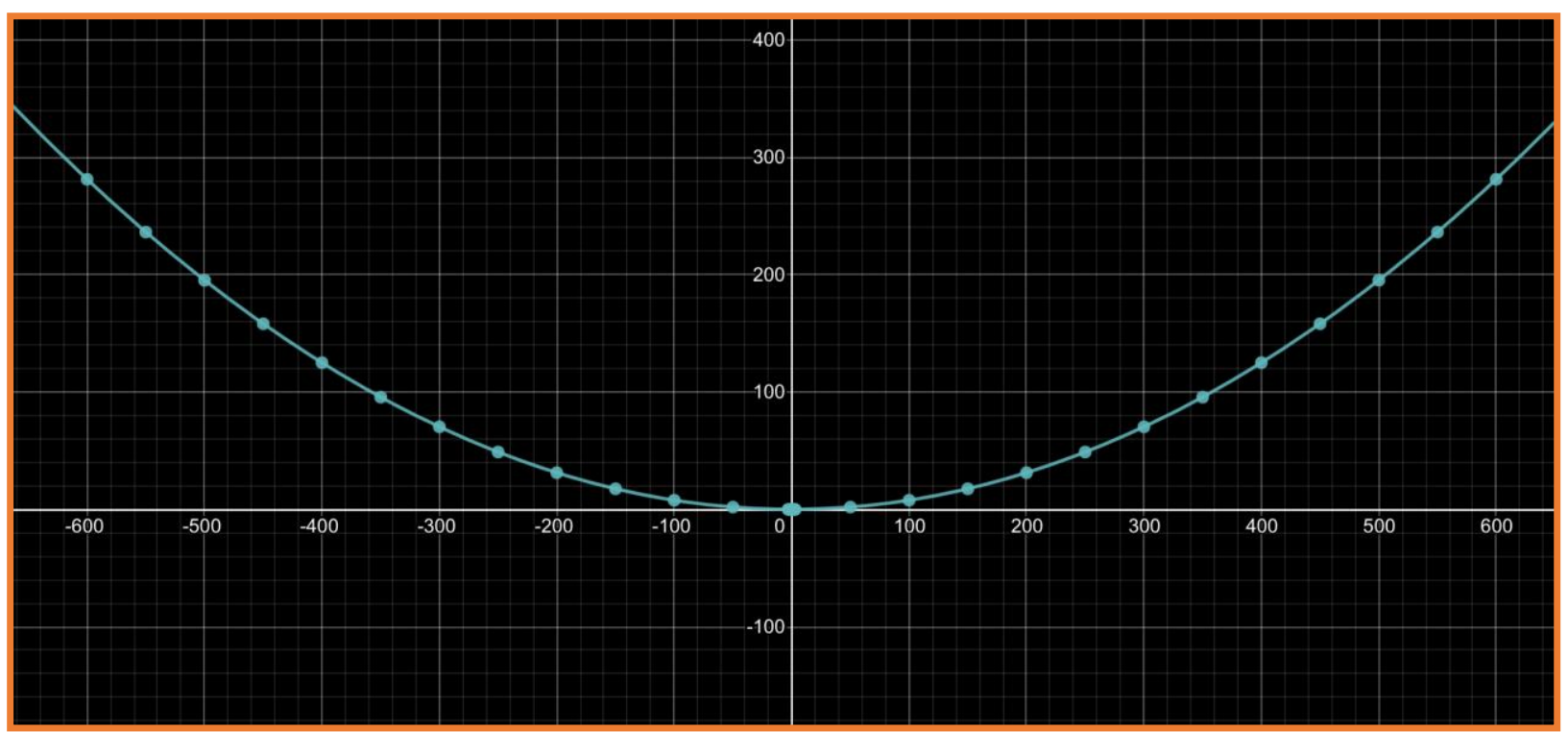


Fabrication works and assembly works: -
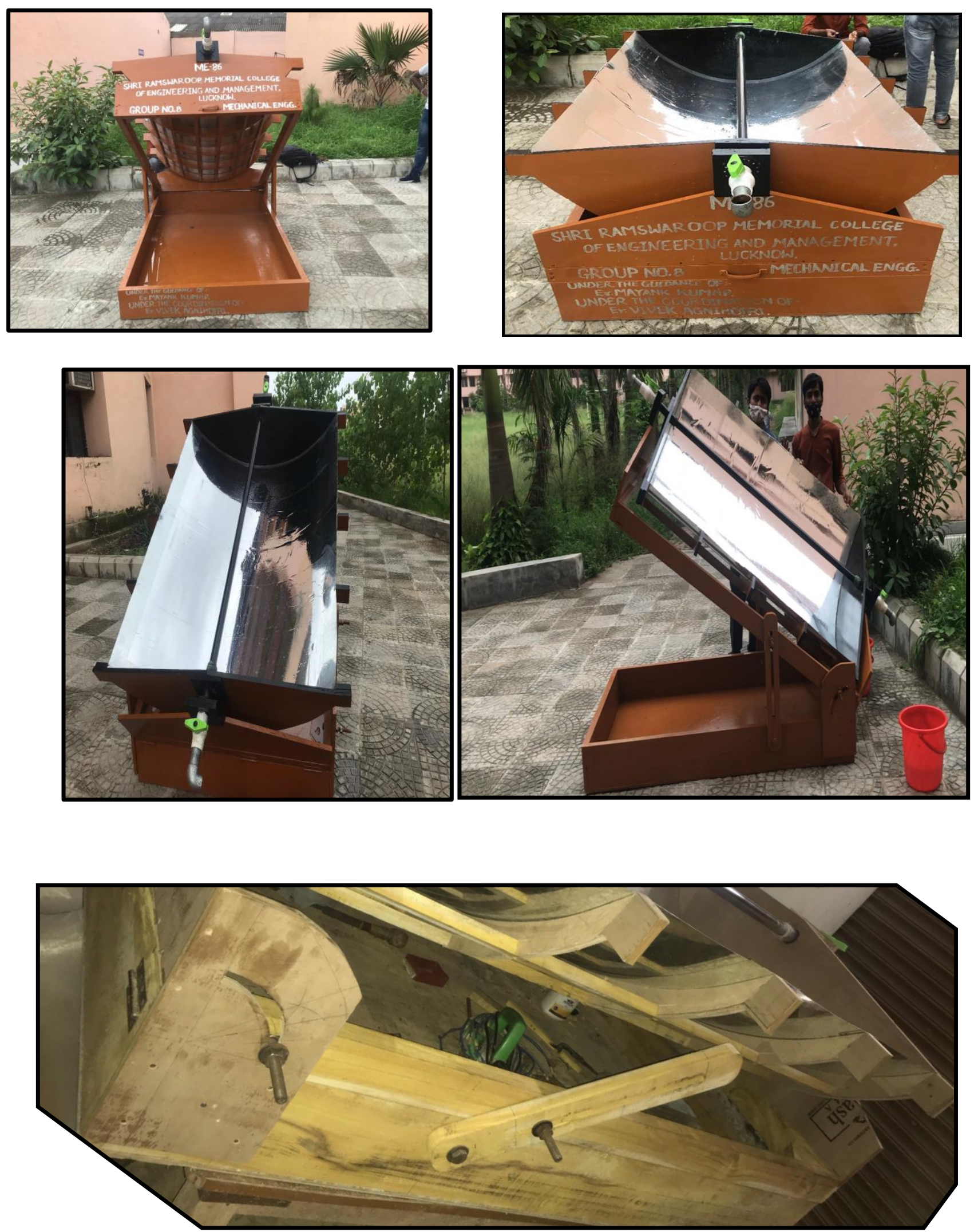

Fig.. Tracking mechanism for frame fitted with nut and bolts 


\section{International Advanced Research Journal in Science, Engineering and Technology}

Vol. 8, Issue x, Month 2021

\section{DOI: 10.17148/IARJSET.2021.8}

\section{Graph-Plotted:}

The various parameters like heat absorbed by collector, heat absorbed by concentrator, heat gained by water, thermal efficiency for both the absorbers are calculated for the different setups.

The following graphs will be plotted:

1. Time $\mathrm{v} / \mathrm{s}$ Intensity

2. Time v/s Efficiency

3. Absorber plate efficiency v/s Time

Day 1 dated on 3 July 2021

Observation Table 1

\begin{tabular}{|c|c|c|c|c|c|c|c|c|c|}
\hline Time & $\begin{array}{l}\text { Flow } \\
\text { rates } \\
(\mathrm{kg} / \mathrm{hr})\end{array}$ & $\begin{array}{l}\text { Solar } \\
\text { intensity }\end{array}$ & $\begin{array}{l}\text { Water inlet } \\
\text { temperature } \\
\text { e (degree } \\
\text { Celsius) }\end{array}$ & $\begin{array}{l}\text { Water outlet } \\
\text { temperaturee } \\
\text { (Degree } \\
\text { Celsius) }\end{array}$ & $\begin{array}{l}\text { Absor } \\
\text { ber/ } \\
\text { receive } \\
\text { r plate } \\
\text { temper } \\
\text { aturee }\end{array}$ & $\begin{array}{l}\text { Collector } \\
\text { plate } \\
\text { Temperatu } \\
\text { rere } \\
\text { (degree } \\
\text { Celsius) }\end{array}$ & $\begin{array}{l}\text { Heat } \\
\text { available } \\
\text { to the } \\
\text { concentrat } \\
\text { eor }(\mathrm{kJ} / \mathrm{hr})\end{array}$ & $\begin{array}{l}\text { Heat } \\
\text { gained by } \\
\text { water kJ/ } \\
\text { hr }\end{array}$ & $\begin{array}{l}\text { Efficiency } \\
(\%)\end{array}$ \\
\hline 10:00 & $24 \mathrm{~kg} / \mathrm{hr}$ & 3242.77 & 28 & 35.2 & 56.6 & 70 & 3258.5112 & 722.6496 & $22.17 \%$ \\
\hline 11:00 & $24 \mathrm{~kg} / \mathrm{hr}$ & 3252.43 & 28 & 37.1 & 57.4 & 74 & 3170.4594 & 913.3488 & $28.80 \%$ \\
\hline $12: 00$ & $24 \mathrm{~kg} / \mathrm{hr}$ & 3342.25 & 28 & 38.1 & 60.3 & 76.2 & 3258.0156 & 1013.7168 & $31.11 \%$ \\
\hline $13: 00$ & $24 \mathrm{~kg} / \mathrm{hr}$ & 3252.43 & 28 & 40.4 & 65.8 & 78.5 & 3170.4594 & 1244.5632 & $39.25 \%$ \\
\hline $14: 00$ & $24 \mathrm{~kg} / \mathrm{hr}$ & 3116.91 & 28 & 36.7 & 61.2 & 77 & 3038.3548 & 873.2016 & $29.73 \%$ \\
\hline $15: 00$ & $24 \mathrm{~kg} / \mathrm{hr}$ & 3071.74 & 28 & 33.3 & 58.3 & 73.6 & 2994.3233 & 531.9504 & $17.76 \%$ \\
\hline $16: 00$ & $24 \mathrm{~kg} / \mathrm{hr}$ & 2978.08 & 28 & 31.8 & 55 & 69.6 & 2903.0238 & 381.3984 & $13.13 \%$ \\
\hline
\end{tabular}

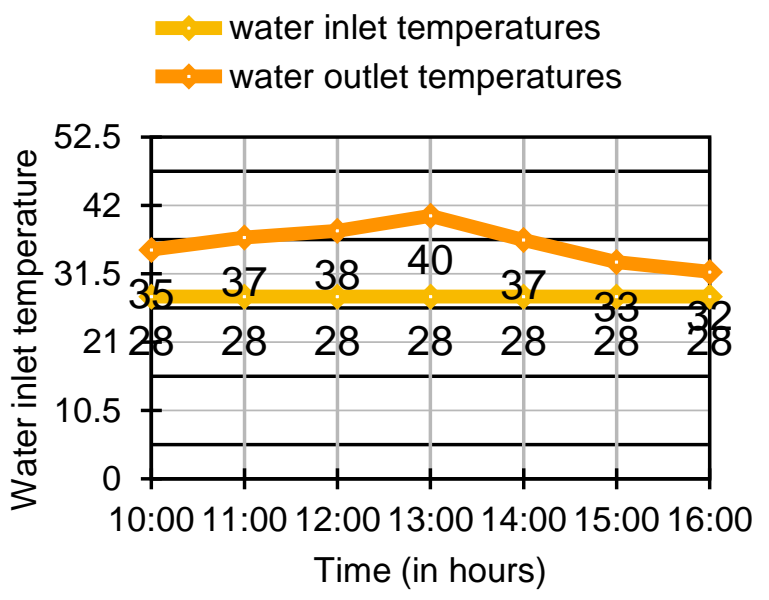

Graph 7.1 plotted between water inlet temperature and water outlet temperature vs Time heat available to the concentrated

heat gained by water

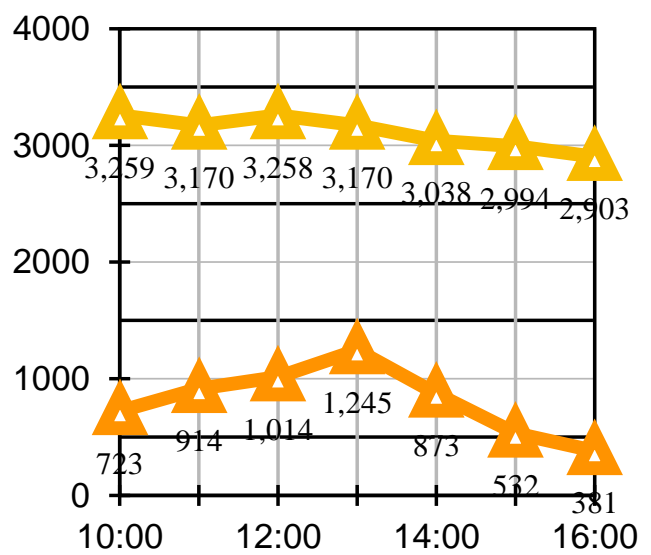

Graph 7.2 heat available to the concentrator and heat gained by water vs time 
International Advanced Research Journal in Science, Engineering and Technology

Vol. 8, Issue x, Month 2021

DOI: 10.17148/IARJSET.2021.8

- absorber plate temperature

- collectors plates temperature

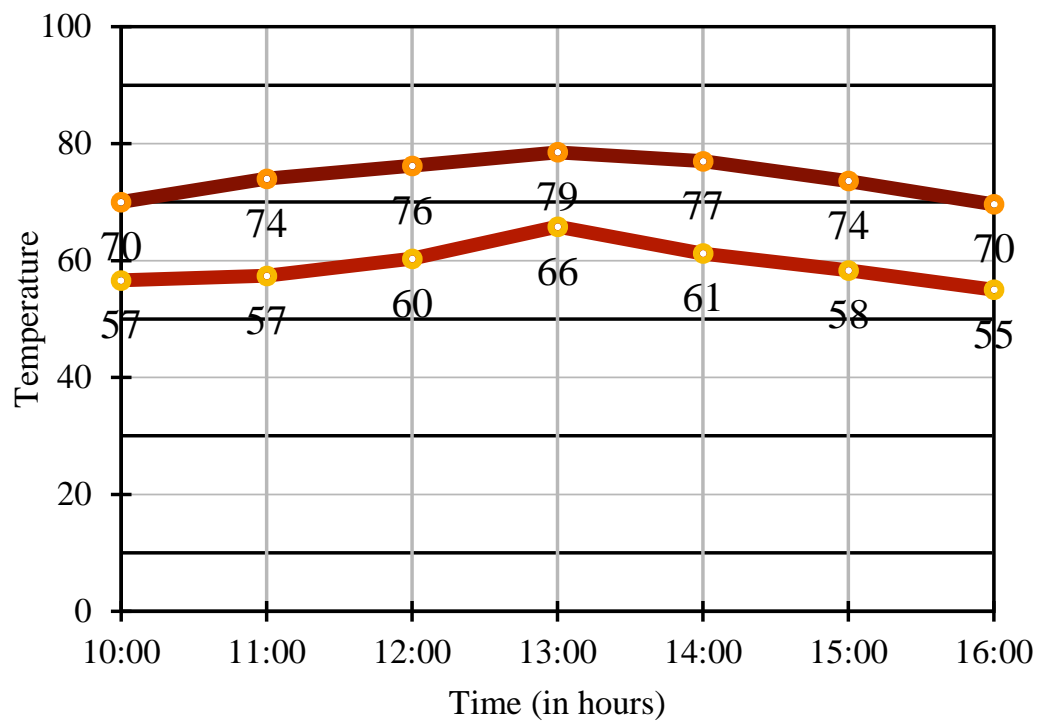

Graph 7.3 . Plotted between absorber plate temperature and collector plate temperature vs Time

Observation Table 2

\begin{tabular}{|c|c|l|l|l|l|l|l|l|l|}
\hline Time & $\begin{array}{l}\text { Flow rates } \\
(\mathrm{kg} / \mathrm{hr})\end{array}$ & $\begin{array}{l}\text { Solar } \\
\text { intensity } \\
(\mathrm{kW} / \mathrm{hr}- \\
\left.\mathrm{m}^{2}\right)\end{array}$ & $\begin{array}{l}\text { Water } \\
\text { inlet } \\
\text { temperatu } \\
\text { re }(\text { degree } \\
\text { Celsius })\end{array}$ & $\begin{array}{l}\text { Water } \\
\text { outlet } \\
\text { temperatu } \\
\text { re } \\
\text { (Degree } \\
\text { Celsius })\end{array}$ & $\begin{array}{l}\text { Absorber/ } \\
\text { receiver } \\
\text { plate } \\
\text { temperatu } \\
\text { re }\end{array}$ & $\begin{array}{l}\text { Collector } \\
\text { plate } \\
\text { Temperat } \\
\text { ure } \\
\text { (degree } \\
\text { Celsius })\end{array}$ & $\begin{array}{l}\text { Heat } \\
\text { available } \\
\text { to the } \\
\text { concentrat } \\
\text { or }(\mathrm{kJ} / \mathrm{hr})\end{array}$ & $\begin{array}{l}\text { Heat } \\
\text { gained by } \\
\text { water } \\
\mathrm{kJ} / \mathrm{hr}\end{array}$ \\
\hline $10: 00$ & 21 & 3297.60 & 32 & 45 & 55 & 64 & 3214.49 & $\begin{array}{l}\text { Efficiency } \\
(\%)\end{array}$ \\
\hline $11: 00$ & 21 & 3342.77 & 32 & 46 & 56 & 67 & 3161.04 & 1229.508 & $38.89 \%$ \\
\hline $12: 00$ & 21 & 3433.12 & 33 & 48.7 & 59 & 68.8 & 3346.59 & 1378.8054 & $41.20 \%$ \\
\hline $13: 00$ & 21 & 3297.6 & 35 & 51.2 & 60 & 70 & 3214.49 & 1422.7164 & $44.25 \%$ \\
\hline $14: 00$ & 21 & 3207.25 & 32 & 45.8 & 57 & 66 & 3126.41 & 1211.9436 & $38.76 \%$ \\
\hline $15: 00$ & 21 & 3116.9 & 31 & 42.1 & 53 & 63 & 3038.34 & 974.8242 & $32.55 \%$ \\
\hline $16: 00$ & 21 & 3071.74 & 30 & 40 & 51 & 62 & 2994.32 & 878.22 & $29.32 \%$ \\
\hline
\end{tabular}




\section{International Advanced Research Journal in Science, Engineering and Technology}

Vol. 8, Issue x, Month 2021

DOI: $10.17148 /$ IARJSET.2021.8

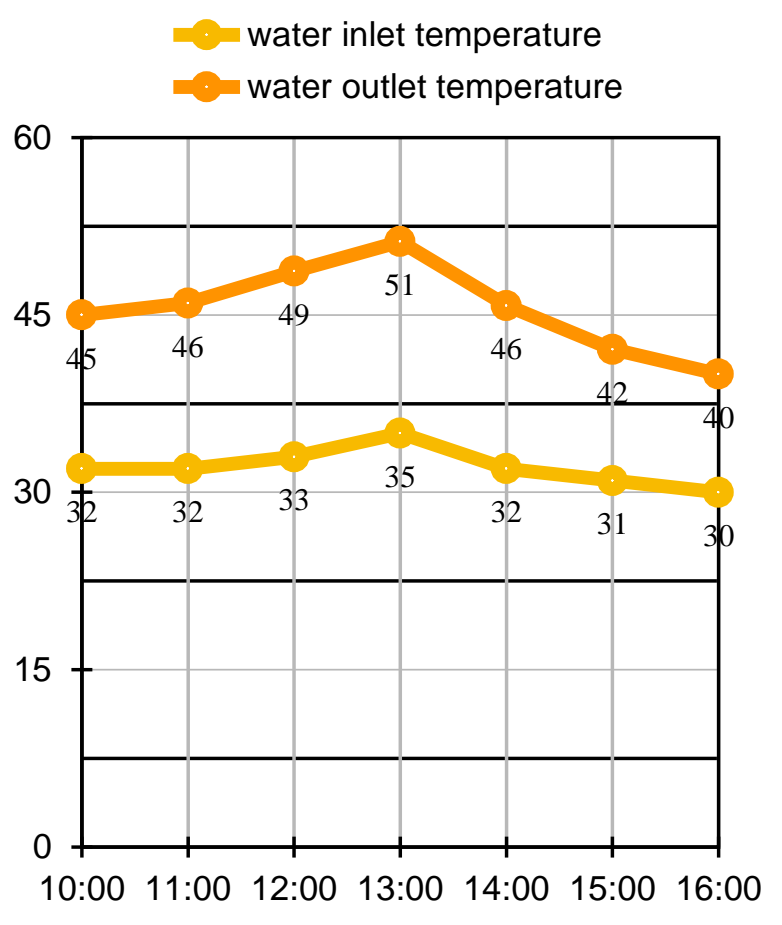

Graph plotted between water inlet temperature ,water outlet temperature vs Time

heat available to the concentrator heat gained by water

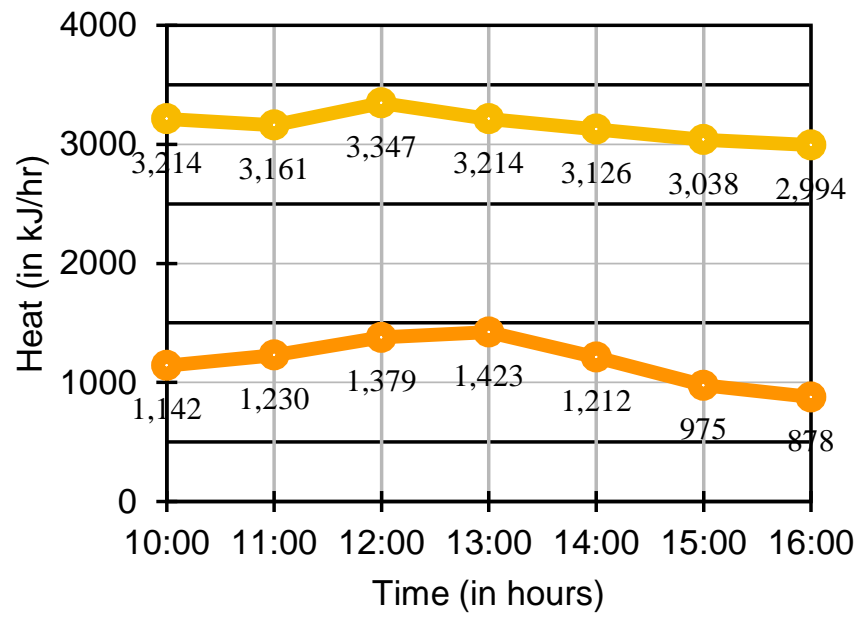

Graph heat vs time

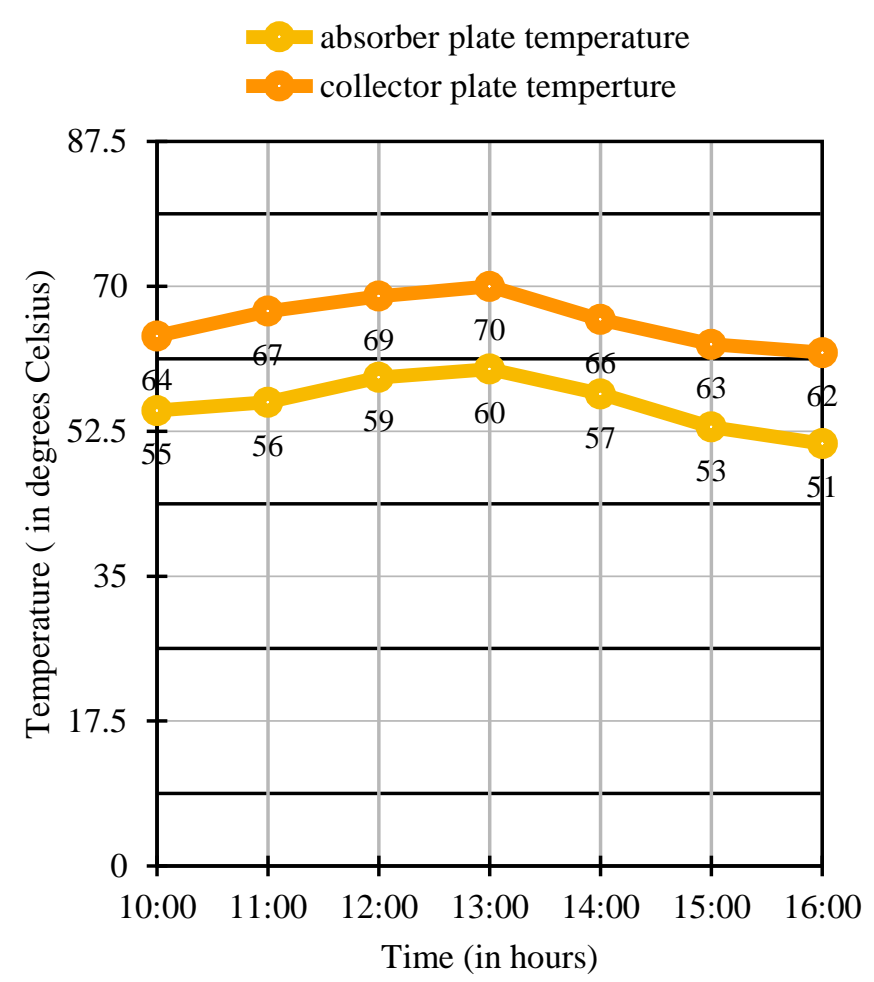

Graph different plates temperature vs Time

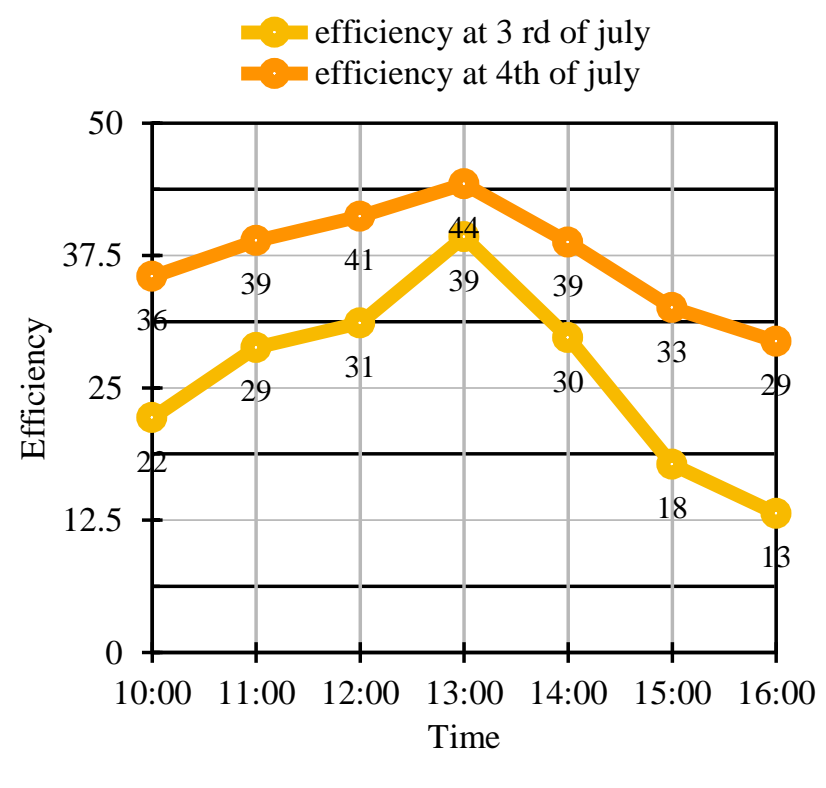

Graph efficiency vs Time

\section{OBSERVATION}

From the observation, we mainly conclude with the following results:

1. Heat available at the concentrator is greater than the heat gained by the water in both days of experiments works.

2. Keeping the water inlet temperature constant at day 1 then we measure the water outlet temperature and on 


\title{
International Advanced Research Journal in Science, Engineering and Technology
}

\author{
Vol. 8, Issue x, Month 2021
}

\section{DOI: $10.17148 /$ IARJSET.2021.8}

day 2 water inlet temperature may vary from 2 or 1 reading and then again measure water outlet temperature and we found that In day 1 there is less increase in temperature of water outlet temperature as compared to Day 2.

3. At comparing their efficiencies of both days, we conclude that the efficiency is much greater when water is heated at high temperature and we also conclude that at different flow the efficiency may increase or decrease.

4. At day 1 the flow rate of water is more we get less or low efficiencies.

5. At day 2 the flow rate of water is less we get high or more efficiencies.

\section{CONCLUSION}

We mainly conclude through the findings of our project how different flow rates play a major role in the working of a solar parabolic trough collector. As the efficiency shown by a parabolic trough collector is more than that of a flat plate collector, there is a scope for wider use as to increase the outcome of such. But there is a short disadvantage of parabolic trough collector as there needs to be a tracking device so as to check the functioning of the parabolic trough type collector. We further see that nature of reflecting surface also plays a major role in the output of the working of a solar collector.

In this project we developed a solar water heating system which gives efficiency which is greater than the system with natural circulation. It shows that time required for obtaining maximum temperature is less for forced circulation as compare to natural circulation solar water heating system. The need of compact sized solar water heating system is fulfilled by our system (Parabolic trough collector system). Our system costs less than conventional flat plate collector system available in market. In future if the system has to develop further, we can replace our steel surface of collector by glass surface to achieve temperature of $125^{\circ} \mathrm{C}$ and aluminium surface to achieve $103^{\circ} \mathrm{C}$. By using flow control valves different flow rates can be achieved for getting better heating results.

From the observation, we mainly conclude with the following results:

Given the intensity be constant, the efficiency of a parabolic trough collector changes inversely with that of the flow rates. We see an increase of $50-70 \%$ in efficiency when the flow rates is decreased by $33 \%$

Mirror reflecting surface gives better efficiency compared to that of aluminium reflecting surface.

We mainly see the change in the solar intensity from the morning to the evening as the intensity rises in the morning hours and reaches its peak value between 12:30 PM and 1:30 PM then again decreases in the evening hours.

\section{REFERENCES}

1. Grenhout, N.K., Behnia, M. and Morrison, G.L. (2001), Experimental measurement of heat loss in an advanced solar collector, Experimental Thermal and Fluid Science, 26, 131-137

2. Kalogirou, S.A. (1996), Parabolic Trough Collector System for Low Temperature Steam Generation: Design and Performance Characteristics, Applied Energy, 55, Paper 1, 98-132.

3. Kalogirou, S.A., Lyod, S., Ward, J. and Elefteriou, P. (1994), Design and Performance Characteristics of A Parabolic Trough Solar Collector System, Applied Energy, 341-354.

4. Larches, M., Rommel, M., Bohlean, A., Frank, E. and Minder, S. (2013), Characterisation of A Parabolic Trough Collector for Process Heat Applications, ISES Solar World Congress Energy Procedia, 57, 2804-2811.

5. Mace'do-Valenciaa, J., Ramirez-Availaa, J., Acostaa, J., Jaramillob, O.A. and Aguilara, J.O. (2013), Design, Construction and Evaluationof Parabolic Trough Collector as Demonstrative, ISES Solar World Congress Energy Procedia, 57, 989-998.

6. Montesa, I.E.P, Beniteza, A.M., Chaveza, O.M. and Herrerab, A.E.L. (2013) Design and Construction of A Parabolic Trough Solar Collector For Process Heat Production, ISES Solar World Congress, Energy Procedia, 57, 2149-2158.Rai, G.N. (2007), Solar Energy Utilization, Khanna Publishers-2, 120-168.

7. Sandeep, H.M. and Arunachal, U.C. (2017) Solar Parabolic Through Collector: A Review on Heat Transfer Augmentation Techniques, Renewable and Sustainable Energy Reviews, 69, 1218-1231.

8. Sukhatme, S.P. and Nayak, J.K. (2011), Solar Energy, TMH Publications, 240-253.

9. Santosh Kumar Singh Arvind Kumar Singh and Santosh Kumar Yadav, International Journal of Engineering Research \& Technology (IJERT) Vol. 1 Issue 10, December- 2012 ISSN: 2278-0181, Design and Fabrication of Parabolic Trough Solar Water Heater for Hot Water Generation.

10. Patil Digvijay Tanaji, Patil Ashish Anand, International Journal of Advance Research in Science and Engineering, Vol. 2, Issue No. 12 December 16 Parabolic Trough Collector Based Solar Water Heating System Using Forced Circulation.

11. Samia Tabassum, Laila Sharmin, Muhammad Shahrir Bhashar, Mashudur Rahman, Sumon Chandra Debnath, Mahfuza Khanam, Journal of Architectural Environment and Structural Engineering Research, Design and Analysis of Parabolic Through Solar Water Heating System. 